\title{
Efektivitas ekstrak umbi sarang semut (myrmecodia pendens merr.\& perry) sebagai penurun kadar glukosa darah tikus sprague dawley yang diabetes mellitus
}

\author{
Maxianus Kopong Raya ${ }^{1}$, Anang M. Legowo ${ }^{2}$, Noor Wijayahadi ${ }^{3}$
}

\begin{abstract}
Background : Diabetes Mellitus (DM) is a disease associated with pancreatic $\beta$ cell damage and causes hyperglycemia Antioxidants were effective in reducing the state of hyperglycemia that was triggered by free radicals. Sarang semut contains flavonoids and tannins that act as antioxidants.

Objective : The purpose to analyze the effectiveness of sarang semut stem extract as lowering blood glucose on diabetic white male Sprague Dawley rats.

Method : True experimental with 30 rats which divided into five groups : negative control (DM+ water), positive control (DM+glibenklamid) and 3 treatment groups of DM + water extract of sarang semut stem powder $90 \mathrm{mg} / 200 \mathrm{gBW}, 180$ $\mathrm{mg} / 200 \mathrm{~g} \mathrm{BW}$ and 360/200g BW respectively. DM was induced by $65 \mathrm{mg} / \mathrm{kgBW}$ Streptozotocin and $230 \mathrm{mg} / \mathrm{kgBW}$ Nicotinamide intraperitonealy. Extract was given by sonde. The data was analyzed by Kruskall-Wallis and Mann-Whitney.

Results : IC 50 value of sarang semut stem extract were 6,56-10,07 mg/ml in powder and 9,12-15,62 $\mathrm{mg} / \mathrm{ml}$ whole. The average rats weight alteration on groups of negative control, positive control, and 3 treatment groups of DM + water extract of sarang semut stem powder $90 \mathrm{mg} / 200 \mathrm{gBW}, 180 \mathrm{mg} / 200 \mathrm{~g} \mathrm{BW}$ and 360/200g BW before and after treatment were -7,60 $\pm-0,40$;

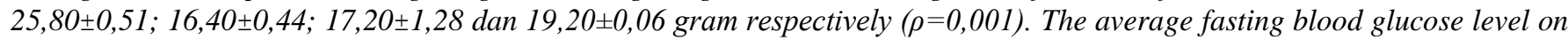
groups of negative control, positive control, and 3 treatment groups of DM + water extract of sarang semut stem powder 90

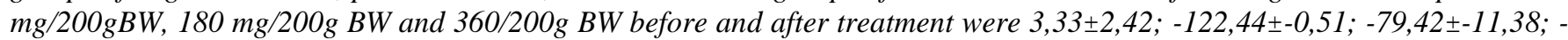
$94,08 \pm-11,97$ and $-134,66 \pm-2,59 \mathrm{mg} / \mathrm{dL}$ respectively $(\rho=0,001)$.

Conclusion : The $I_{50}$ value in sarang semut stem powder was higher than a whole form. Dose of $360 \mathrm{mg} / 200 \mathrm{~g} B W$ lowered blood glucose better than 90 and 180 /200g BW dosage.
\end{abstract}

Keywords : Diabetes mellitus, sarang semut stem, water extract, fasting blood glucose

\section{ABSTRAK}

Latar belakang : Diabetes Mellitus (DM) adalah penyakit yang berhubungan dengan kerusakan sel $\beta$ pankreas dan menyebabkan hiperglikiemia. Antioksidan efektif dalam menurunkan keadaan hiperglikemia yang dipicu radikal bebas. Sarang semut mengandung flavonoid dan tanin yang berfungsi sebagai antioksidan.

Tujuan : Mengkaji efektivitas ekstrak umbi sarang semut sebagai penurun kadar glukosa darah tikus Sprague Dawley diabetes mellitus.

Metode : Eksperimen murni, menggunakan 30 tikus dibagi secara acak menjadi 5 kelompok : kontrol negatif (DM+air), kontrol positif (DM+glibenklamid) dan 3 kelompok perlakuan berturut-turut DM+ekstrak air dari simplisia umbi sarang semut 90 mg/200 g BB, 180 mg/200 g BB dan 360 mg/200 g BB. Induksi DM menggunakan Streptozotocin 65 mg/kg BB dan Nicotinamide $230 \mathrm{mg} / \mathrm{kg}$ BB intraperitoneal. Ekstrak umbi sarang semut diberikan secara sonde. Analisis data dengan Kruskall-Wallis dan Mann-Whitney.

Hasil : Nilai IC 50 ekstrak umbi sarang semut bubuk 6,56 - 10,07 mg/ml dan utuh 9,12 - 15,62 mg/ml. Rerata perubahan berat badan tikus awal dan akhir perlakuan kelompok kontrol negatif, kontrol positif, dosis $90 \mathrm{mg} / 200 \mathrm{~g} \mathrm{BB,} 180 \mathrm{mg} / 200 \mathrm{~g} \mathrm{BB} \mathrm{dan}$

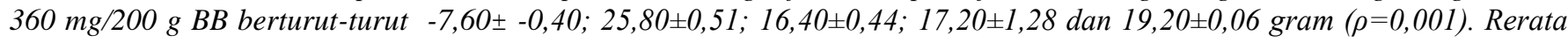
perubahan kadar glukosa darah awal dan akhir perlakuan kelompok kontrol negatif, kontrol positif, dosis $90 \mathrm{mg} / 200 \mathrm{~g}$ BB,

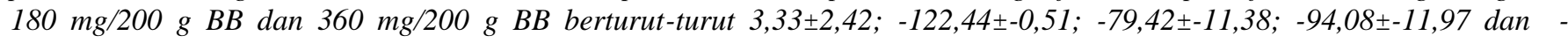
134,66士-2,59 $\mathrm{mg} / \mathrm{dL}(\rho=0,001)$.

Simpulan : Nilai IC 50 ekstrak umbi sarang semut bubuk lebih tinggi dari bentuk utuh. Pemberian ekstrak umbi sarang semut dosis 360 mg/200 g BB menurunkan glukosa darah puasa lebih baik dibandingkan dosis 90 dan $180 \mathrm{mg} / \mathrm{kg} \mathrm{BB.}$

Kata kunci : Diabetes mellitus, ekstrak umbi sarang semut, glukosa darah

\section{PENDAHULUAN}

Diabetes Mellitus (DM) merupakan suatu

1. Prodi Gizi Poltekkes Kemenkes Jayapura

2. Fakultas Peternakan dan Pertanian, Universitas Diponegoro, Semarang (email korespondensi : anang_ml@yahoo.com)

3. Fakultas Kedokteran, Universitas Diponegoro, Semarang gangguan kesehatan atau penyakit dimana tubuh penderita tidak bisa secara otomatis mengendalikan tingkat konsentrasi gula (glukosa) dalam darahnya ${ }^{1}$. Penderita diabetes tidak bisa memproduksi insulin dalam jumlah yang cukup, sehingga terjadi kelebihan gula dalam darah. Kelebihan gula yang kronis dalam darah (hiperglikemia) tersebut akan menjadi racun dalam tubuh ${ }^{2}$. 
Menurut data Organisasi Kesehatan Dunia (WHO), Indonesia menempati urutan keempat di dunia sebagai negara dengan jumlah penderita DM terbanyak setelah India, China, dan Amerika Serikat. Tercatat pada tahun 2000, jumlah penderita diabetes di Indonesia mencapai 8,5 juta sehingga pada tahun 2030 diperkirakan akan mencapai 22 juta penderita ${ }^{3}$.

Diabetes Mellitus (DM) adalah penyakit yang berkorelasi dengan kerusakan sel $\beta$ pankreas karena adanya radikal bebas dalam tubuh. Dengan rusaknya sel $\beta$ pankreas dapat menyebabkan kekurangan hormon insulin.

Penelitian membuktikan bahwa stress oksidatif, keadaan hiperglikemia yang dipicu radikal bebas berpengaruh terhadap perkembangan penyakit diabetes ${ }^{4}$. Hal ini juga berarti bahwa antioksidan merupakan strategi efektif dalam menurunkan komplikasi penyakit, terutama dari sumber hayati, salah satunya adalah kelompok flavonoid.

Uji penapisan kimia dari tumbuhan sarang semut menunjukkan bahwa tumbuhan ini mengandung senyawa - senyawa kimia dari golongan flavonoid dan tanin. Hal ini sesuai dengan hasil penelitian yang telah dilakukan oleh para peneliti lain sebelumnya yang mempelajari golongan senyawa ini dalam kaitannya dengan sistem pertahanan diri tumbuhan sarang semut.

Flavonoid merupakan golongan senyawa bahan alam dari senyawa fenolik yang banyak merupakan pigmen tumbuhan dan merupakan bagian penting bagi manusia karena banyak manfaatnya bagi kesehatan. Fungsi utama flavonoid dalam tubuh manusia adalah sebagai antioksidan alam yang mampu bertindak sebagai pereduksi radikal hidroksil, superoksida dan radikal peroksil ${ }^{6}$. Flavonoid juga mengandung 313 ppm tokoferol yang meredam $96 \%$ radikal bebas pada konsentrasi $12 \mathrm{ppm}$. Persentase inhibisi ini tetap konstan hingga konsentrasi yang lebih tinggi ${ }^{7}$. Manfaat lain dari flavonoid adalah untuk melindungi struktur sel, memiliki hubungan sinergis dengan vitamin $\mathrm{C}$, antiinflamasi dan sebagai antibiotik.

Penelitian tentang efek ekstrak sarang semut terhadap kadar glukosa darah pada tikus putih jantan galur Sprague dawley yang diinduksi streptozotocin belum pernah dilakukan hingga saat ini. Oleh karena itu perlu dilakukan penelitian tentang efektivitas antioksidan ekstrak sarang semut terhadap kadar glukosa darah pada tikus putih jantan galur Sprague dawley yang diinduksi streptozotocin. Penggunaan ekstrak air, didasarkan pada kebiasaan masyarakat dalam mengkonsumsi bagian tanaman ini.

Tujuan dari penelitian ini adalah mengevaluasi aktivitas antioksidan ekstrak umbi sarang semut dalam bentuk kering dan bubuk yang diekstrak dengan air dan mengkaji dosis konsumsi ekstrak umbi sarang semut yang dapat memberikan pengaruh terhadap penurunan kadar glukosa darah pada tikus putih jantan galur SD yang diabetes mellitus.

\section{BAHAN DAN METODE}

Ruang lingkup penelitian adalah bidang ilmu gizi, termasuk penelitian eksperimen murni bidang gizi dengan pendekatan pre and post randomized controlled group design. Penelitian menggunakan tikus putih jantan galur SD yang diinduksi STZ dosis $65 \mathrm{mg} / \mathrm{kg}$ BB dan NA $230 \mathrm{mg} / \mathrm{kg} \mathrm{BB}^{8}$, yang dibagi menjadi 5 kelompok, yaitu : kelompok kontrol negatif, kontrol positif dan 3 kelompok perlakuan yang diberi ekstrak dari simplisia umbi sarang semut.

Penelitian ini terbagi dua tahap penelitian yaitu Tahap I pengujian aktivitas antioksidan ekstrak umbi sarang semut dengan metode DPPH, Tahap 2 pengujian daya penurun kadar glukosa darah ekstrak dari simplisia umbi sarang semut pada tikus putih jantan galur SD yang diabetes mellitus.

Pengukuran kadar glukosa dilakukan pada hari ke-5 pasca induksi. Tikus dinyatakan diabetes bila kadar glukosa darah $\geq 200 \mathrm{mg} / \mathrm{dl}^{9}$, selanjutnya kontrol positif diberikan glibenklamid 0,09 mg/200 g BB dan kelompok perlakuan diberikan ekstrak dari simplisia umbi sarang semut dengan dosis 90, 180 dan 360 $\mathrm{mg} / 200 \mathrm{~g}$ BB selama 21 hari. Pada hari ke- 9, 15 dan 21 dilakukan pengukuran kadar gula darah post test I dan II dan III.

Penelitian dilaksanakan di Laboratorium Biokimia Nutrisi Fakultas Peternakan dan Pertanian Universitas Diponegoro untuk pengujian aktivitas antioksidan ekstrak umbi sarang semut, ekstraksi umbi sarang semut dilakukan di Laboratorium Mikrobiologi Makanan Jurusan Gizi Poltekes Kemenkes Semarang, sedangkan pemeliharaan hewan coba, perlakuan dan pemeriksaan kadar glukosa darah tikus putih jantan galur SD yang diabetes mellitus dilaksanakan di Laboratorium Pusat Studi Pangan dan Gizi, PAU Universitas Gadjah Mada Yogyakarta.

Subjek dalam penelitian ini adalah tikus putih jantan (Rattus norvegicus) galur SD yang berusia 8 12 minggu, diperoleh dari Laboratorium Pusat Studi Pangan dan Gizi, PAU UGM Yogyakarta.

Jumlah hewan coba yang digunakan dalam penelitian ini ditentukan menggunakan rumus Faderer. ${ }^{10}$ Jumlah minimal hewan coba yang digunakan adalah 5 ekor. Untuk menghindari kekurangan jumlah hewan coba, masing-masing kelompok akan ditambah 2 ekor sehingga dibutuhkan sebanyak 30 ekor hewan coba.

Teknik pengambilan sampel sebanyak 30 ekor tikus dilakukan secara random sampling, terbagi menjadi 5 kelompok, yaitu Kelompok I : kontrol negatif (tikus DM + air), Kelompok II : kontrol positif (tikus DM + glibenklamid 0,009mg/200 g BB), dan 3 
kelompok perlakuan berturut-turut $\mathrm{DM}+\mathrm{ekstrak}$ air dari simplisia umbi sarang semut $90 \mathrm{mg} / 200 \mathrm{~g} \mathrm{BB}$, $180 \mathrm{mg} / 200 \mathrm{~g} \mathrm{BB}$ dan $360 \mathrm{mg} / 200 \mathrm{~g} \mathrm{BB}$.

Bahan - bahan yang dibutuhkan dalam penelitian ini adalah umbi sarang semut jenis Myrmecodia pendens Merr.\&Perry yang berumur $\geq 2$ tahun dan diambil dari daerah Pegunungan Tengah Papua (Wamena), tikus jantan putih (Rattus norvegicus galur Sprague dawley) umur 8-12 minggu dengan berat 140 - $200 \mathrm{~g}$ dan yang memenuhi kriteria inklusi, pakan standar American Institute of Nutrition 93 (AIN 93), Glucose GOD FS Kit, buffer phospat (pH 7,5) dan Glucose Oxidase Phenol 4-Aminophenazone. Alat yang dibutuhkan dalam penelitian ini jarum steril 3 $\mathrm{ml}$, vortex, mikropipet, cuvet dan spektrofotometer, timbangan digital, kandang hewan,

Bahan yang digunakan dalam pembuatan ekstrak umbi sarang semut adalah sarang semut Myrmecodia pendens Merr.\&Perry. Untuk memastikan jenis sarang semut yang digunakan adalah jenis Myrmecodia pendens Merr.\&Perry maka dilakukan uji identifikasi bahan di Laboratorium Biologi Universitas Diponegoro.

Metode ekstraksi dengan air sebagai berikut, umbi sarang semut yang telah dikeringkan dengan sinar matahari selama 2-3 hari, sebagian dibiarkan utuh kering dan sebagian dihancurkan. Umbi sarang semut kering utuh dan yang bubuk kemudian diekstrak dengan air dengan perbandingan 1:10 (b/v), dimaserasi pada suhu $50^{\circ} \mathrm{C}$ selama $3 \times 24$ jam, ekstrak yang diperoleh disaring ${ }^{11}$ untuk diuji aktivitas antioksidannya.

Pengujian aktivitas antioksidan ekstrak umbi sarang semut menggunakan metode DPPH. Pengujian aktivitas antioksidan pada ekstrak umbi sarang semut dilakukan pada suhu $30^{\circ} \mathrm{C}$ dan $50^{\circ} \mathrm{C}$ selama $3 \times 24$ jam, $70^{\circ} \mathrm{C}$ selama 30 menit serta $90^{\circ} \mathrm{C}$ selama 15 menit untuk melihat aktivitas antioksidan. Parameter yang digunakan untuk mengukur aktivitas aktioksidan adalah $\mathrm{IC}_{50}$. Semakin kecil konsentrasi $\mathrm{IC}_{50}$, maka semakin besar aktivitas antioksidannya. Larutan DPPH 0,5 $\mathrm{mM}$ dipersiapkan dengan cara melarutkan DPPH dalam metanol dan buffer asetat $\mathrm{pH} 5,5$. Ekstrak umbi sarang semut diambil sebanyak $0,1 \mathrm{ml}$, ditambahkan $2 \mathrm{ml}$ asam asetat; $1,9 \mathrm{ml}$ metanol dan 1 $\mathrm{ml}$ larutan DPPH untuk selanjutnya disebut larutan sampel. Komposisi blanko seperti larutan sampel tetapi tanpa penambahan DPPH, sedangkan larutan kontrol terdiri dari $2 \mathrm{ml}$ buffer asetat; $1 \mathrm{ml} \mathrm{DPPH}$ dan $2 \mathrm{ml}$ etanol. Selanjutnya larutan sampel dan kontrol di homogenisasi. Blanko, kontrol dan sampel diinkubasi selama 30 menit di ruang gelap pada suhu ruang. Diukur absorbansinya pada $\lambda 517 \mathrm{~nm}$ dengan menggunakan spektrometer. Prosentase aktivitas penghambatan dihitung dengan rumus ${ }^{12}$ :

$$
\text { Nilai } \mathrm{IC}_{50}=\frac{\left[\mathrm{A}_{\text {kontrol }}-\left(\mathrm{A}_{\text {sampel }}-\mathrm{A}_{\text {blanko }}\right)\right]}{-\mathrm{A}_{\text {kontrol }}}
$$

Nilai IC50 sampel dihitung dengan menggunakan rumus regresi persamaan linear

Sebelum digunakan untuk percobaan, tikus putih jantan galur SD diadaptasi terlebih dahulu selama 7 hari. Makanan dan minuman diberikan secara ad libitum berupa pakan standar AIN 93. Berat tikus ditimbang sebagai data dasar, selanjutnya dibagi secara acak menjadi 5 kelompok, yakni kontrol negatif, kontrol positif dan 3 kelompok perlakuan masing - masing 5 ekor tikus. Ekstrak dari simplisia umbi sarang semut diberikan secara sonde, sedangkan pemberian pakan dan minuman secara ad libitum.

\section{Induksi STZ, NA dan pengukuran kadar glukosa darah.}

Tikus yang telah diadaptasi selama 1 minggu kemudian diambil darahnya untuk diukur kadar glukosa awal, selanjutnya diinduksi dengan STZ secara intraperitoneal dosis $65 \mathrm{mg} / \mathrm{kg}$ BB dan NA dosis $230 \mathrm{mg} / \mathrm{kg}$ BB pada 5 kelompok perlakuan. Pengambilan darah untuk pengukuran kadar glukosa darah dilakukan pada hari ke-5 pasca induksi (pre test), hari ke-9, 15 dan hari ke-21, sebagai post test I,II dan III. Pengukuran kadar glukosa darah dilakukan secara kuantitatif dengan metode Enzymatic Colorimetric Test GOD - PAP melalui plexus retro orbitalis.

\section{Pemberian sonde ekstrak dari simplisia umbi sarang semut.}

Ekstrak umbi sarang semut bubuk yang memiliki aktivitas antioksidan yang terbaik digunakan sebagai bahan untuk diberikan pada tikus percobaan. Umbi sarang semut bubuk ditimbang sesuai dengan perlakuan, yaitu 90, 180 dan $360 \mathrm{mg}$. Selanjutnya umbi sarang semut bubuk di ekstraksi dengan pelarut air dengan perbandingan $1 \mathrm{~g}: 10 \mathrm{ml}(\mathrm{b} / \mathrm{v})$ pada suhu $50^{\circ} \mathrm{C} 3 \times 24$ jam.

Ekstrak dari simplisia yang diperoleh kemudian disaring, volume ekstraksi yang diperoleh sekitar 70\% dari berat bahan dan di berikan pada tikus percobaan pada perlakuan III, IV dan V. Sonde diberikan pada tikus selama 21 hari perlakuan setiap pagi hari.

Data dianalisis dengan menggunakan uji Kruskall-Wallis. Bila terdapat perbedaan pengaruh perlakuan maka dilanjutkan dengan uji Mann-Whitney pada taraf $5 \%$. 


\section{HASIL DAN PEMBAHASAN}

\section{Determinasi/Identifikasi Sampel.}

Hasil identifikasi sampel, diperoleh data hasil klasifikasi sebagai berikut: ${ }^{13,14}$

Kelas : Magnoliopsideae-Dycotyledoneae

Ordo : Gentianales (Rubiales)

Family : Rubiaceae

Species : : Myrmecodia pendens Merr.\&Perry

\section{Uji Aktivitas Antioksidan Ekstrak Umbi Sarang Semut.}

Berdasarkan hasil uji penapisan kimia dari tumbuhan obat sarang semut yang dilakukan menunjukkan bahwa tumbuhan ini mengandung senyawa-senyawa kimia dari golongan flavonoid, tokoferol dan tanin. Sarang semut juga kaya akan berbagai mineral yang berguna sebagai antioksidan dan anti kanker, sehingga sarang semut tepat digunakan untuk pengobatan kanker atau tumor ${ }^{7}$

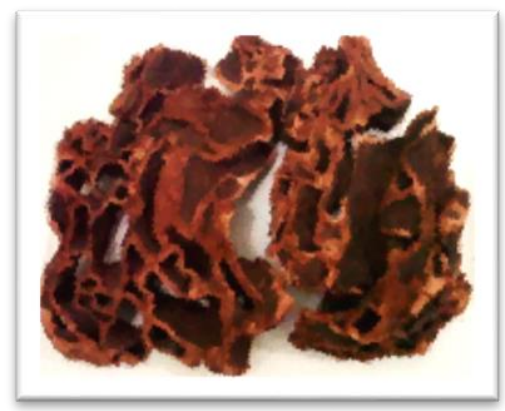

Gambar 1. Myrmecodia pendens Merr.\&Perry

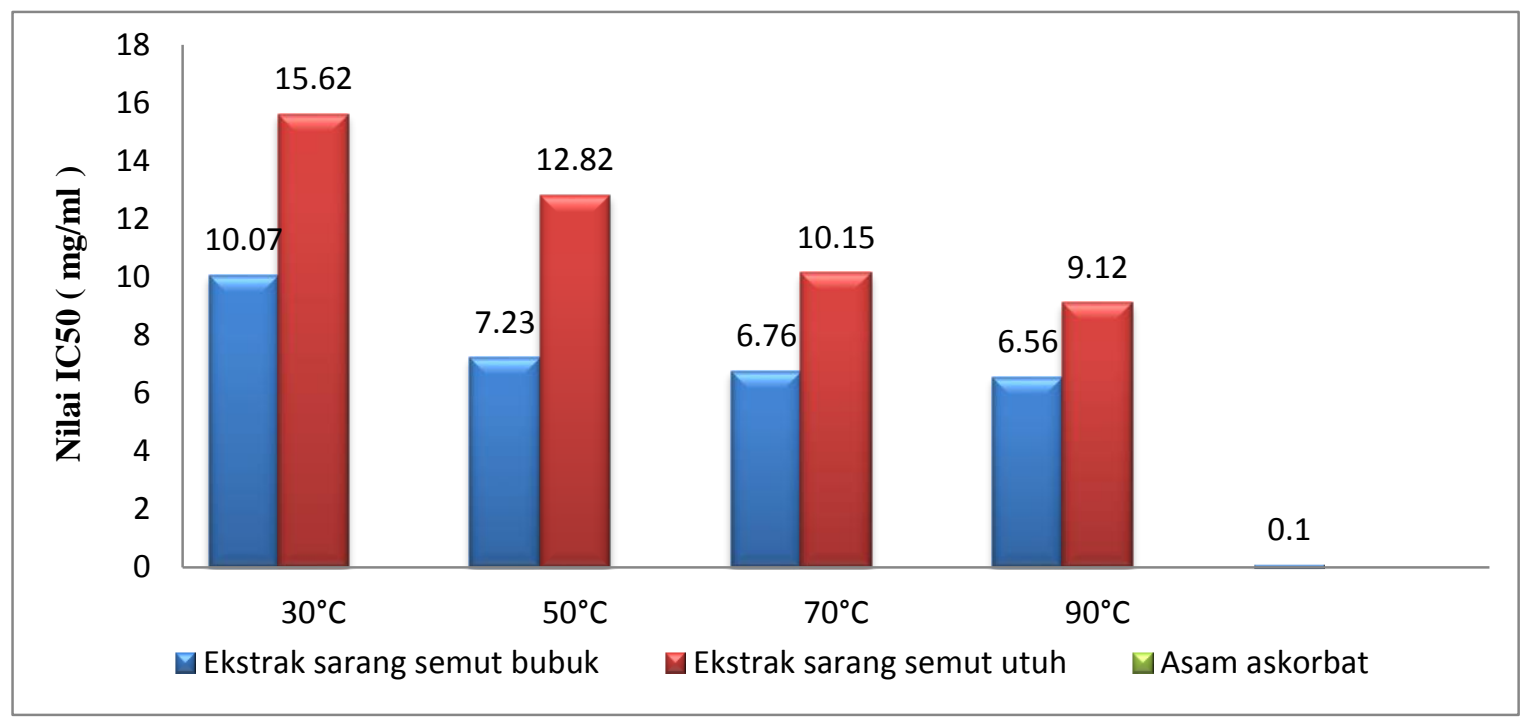

Gambar 2. Hasil Analisis Aktivitas Antioksidan Ekstrak Umbi Sarang Semut

Parameter yang digunakan untuk menghitung aktivitas antioksidan adalah $\mathrm{IC}_{50}$. Semakin kecil nilai $\mathrm{IC}_{50}$, maka semakin besar aktivitas antioksidannya. Hasil pengujian aktivitas antioksidan ekstrak umbi sarang semut mempunyai nilai $\mathrm{IC}_{50}$ berkisar antara 6,56 $10,07 \mathrm{mg} / \mathrm{ml}$ untuk ekstrak umbi sarang semut yang bubuk dan nilai $9,12-15,62 \mathrm{mg} / \mathrm{ml}$ untuk ekstrak umbi sarang semut utuh. Hal ini menunjukkan bahwa ekstrak umbi sarang semut bentuk bubuk memiliki nilai $\mathrm{IC}_{50}$ yang lebih rendah dibandingkan dengan ekstrak umbi sarang semut bentuk kering utuh.

\section{Berat Badan Tikus Percobaan.}

Rerata berat badan tikus percobaan awal adaptasi, awal induksi STZ dan awal perlakuan pemberian ekstrak umbi sarang semut adalah $170,76 \pm 13,24$ gram, $183,92 \pm 13,08$ gram dan $179,00 \pm 12,9$.

Hasil analisis statistik menunjukkan tidak terdapat perbedaan rerata berat badan pada 6 kali pengambilan data berat badan tikus percobaan antar kelompok perlakuan. Hal ini berarti bahwa status berat badan tikus percobaan homogen sebelum adanya perlakuan pemberian ekstrak umbi sarang semut. Kenaikan berat badan tikus percobaan setelah diinduksi STZ ditunjukkan pada kelompok perlakuan kontrol positif, perlakuan I, II dan perlakuan III, sedangkan untuk kontrol negatif terjadi penurunan berat badan pada tikus percobaan setelah diinduksi STZ.

Penelitian oleh ${ }^{15}$ menjelaskan bahwa paska induksi streptozotocin terjadi atropi otot disertai 
penurunan massa otot skelet serta adanya kehilangan protein struktural karena tidak adanya karbohidrat yang digunakan dalam metabolisme energi sehingga terjadi penurunan berat badan. Induksi STZ pada tikus diabetes dikaitkan dengan hilangnya karakteristik berat badan yang disebabkan oleh pengecilan otot dan karena hilangnya protein jaringan $^{16}$.

Menurut ${ }^{17}$, penurunan berat badan dari tikus diabetes mungkin karena dehidrasi dan katabolisme lemak dan protein yang meningkat, menyebabkan pengecilan otot, mungkin juga berkontribusi terhadap penurunan berat badan pada tikus diabetes. Selain itu, peningkatan sekresi insulin juga dapat mengakibatkan sintesis protein meningkat karena efek anaboliknya.

Pemberian ekstrak dari simplisia umbi sarang semut selama 21 hari mampu menaikkan berat badan tikus percobaan. Peningkatan berat badan pada perlakuan III lebih baik dibandingkan perlakuan I dan perlakuan II. Hal ini menunjukkan pemberian ekstrak dari simplisia umbi sarang semut berfungsi sebagai ameliorant, menghambat kerusakan sel $\beta$ akibat pemberian STZ. Terhambatnya kerusakan sel beta akibat pemberian ekstrak umbi sarang semut, maka produksi insulin lebih tinggi dibandingkan tikus yang disuntik STZ tanpa pemberian ekstrak umbi sarang semut.

Tikus percobaan yang diberi ekstrak dari simplisia umbi sarang semut mempunyai kemampuan yang lebih baik dalam memanfaatkan glukosa sebagai sumber energi sehingga tidak membongkar cadangan energi yang tersimpan dalam jaringan lemak maupun sebagai protein, sehingga penurunan berat badan tidak terjadi pada tikus ini. Selain itu adanya produksi insulin yang tetap tinggi menyebabkan tikus ini mampu memasukkan glukosa hasil pencernaan ke dalam sel sehingga bisa diubah menjadi glikogen sebagai glukosa otot sebagai simpanan. Tikus diabetes yang diberi perlakuan dengan ekstrak umbi sarang semut dapat mengalami kenaikan berat badan secara normal. Peningkatan berat badan tikus percobaan diduga tikus mengalami gejala kelaparan dan meningkatkan asupan makanan ${ }^{18}$.

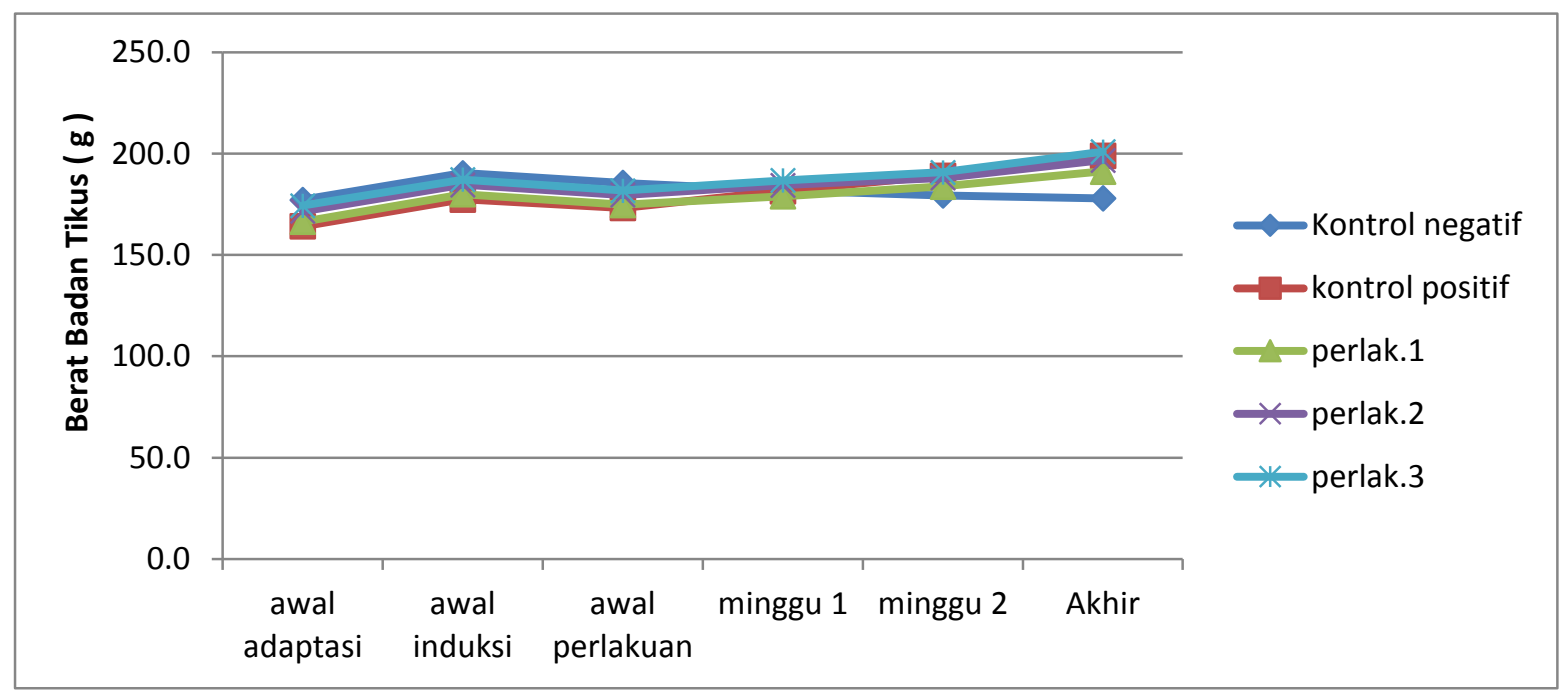

Gambar 3. Grafik Rerata Berat Badan Tikus Percobaan

\section{Kadar Glukosa Darah.}

Kadar glukosa darah mengalami peningkatan setelah diinduksi STZ dan NA pada ke-5 kelompok perlakuan melebihi kriteria diabetes mellitus menurut ${ }^{9}$ yakni $\geq 200 \mathrm{mg} / \mathrm{dl}$. Nilai rerata kadar glukosa darah awal adaptasi tikus percobaan adalah 78,20 $\pm 1,88$, lima hari paska diinduksi STZ adalah 233,13 $\pm 9,51$ dan

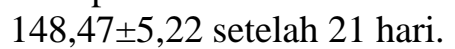

Pemberian ekstrak dari simplisia umbi sarang semut selama 21 hari mengakibatkan terjadinya penurunan kadar glukosa darah tikus percobaan walaupun belum mencapai kadar glukosa darah normal.

Hasil uji Kruskall-Wallis terdapat perbedaan yang bermakna kadar glukosa darah antar kelompok perlakuan dengan $\rho=0,000$. Hasil uji lanjut MannWhitney menunjukkan bahwa terdapat perbedaan yang signifikan perubahan kadar glukosa darah antar kelompok perlakuan, kecuali antar kelompok perlakuan I - kelompok perlakuan II. Keadaan diabetes yang ditunjukkan dengan kadar glukosa darah $\geq 200 \mathrm{mg} / \mathrm{dl}$ terjadi pada ke-5 kelompok perlakuan dan pemberian ekstrak dari simplisia umbi sarang semut selama 21 hari mampu menurunkan kadar glukosa darah pada ketiga kelompok perlakuan. Pengambilan darah untuk pengukuran kadar glukosa darah setiap minggu (hari ke-9, 15 dan hari ke-21) dimaksudkan untuk melihat tren perubahan kadar glukosa darah selama penelitian. 


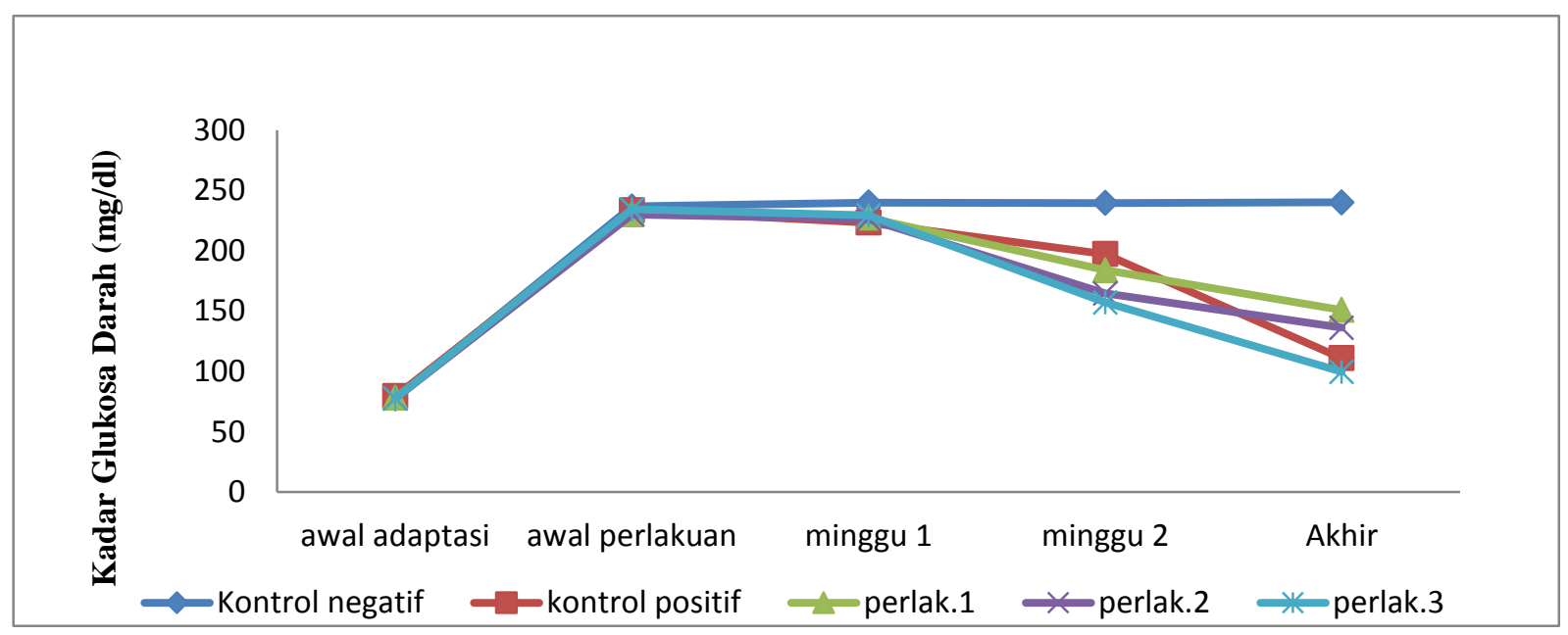

Gambar 4. Grafik Rerata Kadar Glukosa Darah Tikus Percobaan

Penurunan kadar glukosa darah ini diduga disebabkan oleh peran antioksidan flavonoid dan tokoferol dalam menangkal radikal bebas. Disamping itu kandungan selain kelompok flavonoid yang terdapat dalam ekstrak umbi sarang semut adalah mineral magnesium yang ikut berperan sebagai agen hipoglikemik.

Antioksidan telah terbukti mengurangi keadaan yang memburuk dari diabetes dengan meningkatkan fungsi sel $\beta$ pankreas pada hewan percobaan. Hal ini menunjukkan bahwa antioksidan dapat meningkatkan mekanisme sistem kekebalan tubuh. Pengendalian hiperglikemia mengarah pada perbaikan stres oksidatif dan antioksidan dapat meningkatkan mekanisme pertahanan diri sel $\beta$ pankreas dalam mengatasi stres oksidatif ${ }^{20}$.

Terapi dengan ekstrak dari simplisia umbi sarang semut diduga memiliki mekanisme hipoglikemik melalui inaktivasi radikal bebas peroksida yang menyerang sel $\beta$ pankreas, sehingga sel $\beta$ pankreas dapat mensekresi insulin secara baik. Uji penapisan kimia dari tumbuhan sarang semut menunjukkan bahwa tumbuhan ini mengandung senyawa kimia dari golongan flavonoid ${ }^{7}$. Hal ini sejalan dengan pernyataan ${ }^{21}$, bahwa konsumsi senyawa flavonoid dapat mengurangi radikal peroksida dan radikal hidroksil. Flavonoid dilaporkan memiliki peran utama dalam mengurangi stres oksidatif berhubungan dengan diabetes, yang pada gilirannya membantu pengaturan konsentrasi glukosa plasma ${ }^{22}$.

Meskipun diabetes dapat menyebabkan hypomagnesaemia, Kekurangan magnesium juga telah dianggap sebagai faktor risiko untuk diabetes tipe 2 . Magnesium adalah kofaktor yang diperlukan untuk beberapa enzim yang memainkan peran penting dalam metabolisme glukosa. Penelitian pada hewan telah menunjukkan bahwa kekurangan magnesium memiliki efek negatif pada sinyal pasca-reseptor insulin. Beberapa studi metabolik jangka pendek menunjukkan bahwa suplemen magnesium memiliki efek menguntungkan pada metabolisme glukosa ${ }^{23}$.

Hasil penelitian ${ }^{24}$, menyatakan bahwa ekstrak kulit batang bungur (lagerstroemia speciosa pers.) yang mengandung tanin mampu menurunkan kadar glukosa darah mencit yang diinduksi aloksan. Senyawa tanin mempunyai aktivitas hipoglikemik dengan meningkatkan glikogenesis, dan juga berfungsi sebagai astringent atau pengkhelat yang dapat mengkerutkan membran epitel usus halus sehingga mengurangi penyerapan sari makanan yang menghambat asupan glukosa dan laju peningkatan glukosa darah tidak terlalu tinggi ${ }^{25}$.

\section{SIMPULAN}

Nilai IC $_{50}$ ekstrak umbi sarang semut dalam bentuk bubuk lebih tinggi dari ekstrak umbi sarang semut dalam bentuk utuh.

Pemberian ekstrak dari simplisia umbi sarang semut dosis 90, 180 dan $360 \mathrm{mg} / 200 \mathrm{~g}$ BB tikus percobaan dapat menurunkan kadar glukosa darah tikus percobaan yang diinduksi dengan STZ. Penurunan kadar glukosa darah lebih rendah terjadi pada dosis $360 \mathrm{mg} / 200 \mathrm{~g}$ tikus percobaan

\section{SARAN}

Perlu adanya penelitian lebih lanjut mengenai proses ekstraksi dengan menggunakan lebih dari 1 jenis pelarut.

Perlu penelitian lebih lanjut dengan memperhitungkan kadar antioksidan yang terdapat dalam pakan yang diberikan selama perlakuan yang dapat mempengaruhi kadar glukosa darah.

Perlu penelitian lebih lanjut mengenai efek ekstrak dari simplisia umbi sarang semut pada manusia yang diabetes mellitus. 


\section{DAFTAR PUSTAKA}

1. Soegondo S. 2009. Diagnosis dan Klasifikasi Diabetes Mellitus Terkini. Penatalaksanaan Diabetes Mellitus Terpadu. Penerbit FKUI. Jakarta

2. ADA (American Diabetes Association), 2005. Diagnosis and Classification of Diabetes Mellitus. Diabetes Care; doi: Diabetes Care 2004 vol.

http://care.diabetesjournals.org/content/27/suppl 1/s5.full

3. WHO, 2009. Country and Regional Data:World. http://www.who.int/diabetes/facts/world_figures/ en/index.html. [Diakses Tanggal 11 Oktober 2012]

4. Mohora, M., M. Greabu, C. Muscurel, C. Duta and A. Totan. 2007. The Sources and Targets of Oxidative Stress In Etiology of Diabetic Complication. Romanian J. Biophys;17(2):63-84

5. Trubus. 2006. Riset Ilmiah Sarang Semut. (Online) http://trubusonline. co.id/mod.php?mod.php?mod=publisher\&op=pri ntarticle\&artid=29 5. [Diakses Tanggal 07 Agustus 2012]

6. Winarsi, H. 2005. Antioksidan Alami dan Radikal Bebas : Potensi dan Aplikasinya dalam Kesehatan. Penerbit Kanisius, Yogyakarta

7. Subroto, M.A. dan S. Hendro. 2008, Gempur Penyakit dengan Sarang Semut. Cetakan III, Penebar Swadaya Jakarta

8. Szkuldeski, T. 2001. The Mechanism of Aloxan and Streptozotocin Action In $\beta$ Cells of the Rat Pancreas. Physiol Res;50:536-56

9. Braunwald, Eugene, Stephen Hauser, L. Dennis, J. Kasper, Larry Jameson, D. Longo and Anthony S. Fauci. 2008. Harrison's Principles of Internal Medicine. $17^{\text {th }}$ ed. McGraw-Hill Companies,Inc, California, United States

10. Faderer, W. 1991. Statistic and Society : Data Collection and Interpretation. $\quad 2^{\text {nd }} e d$. Marcel Dekker New York

11. Harbone, JB. 1987. Metode Fitokimia: Penuntun Cara Modern Menganalisis Tumbuhan. Padmawinata, I Sudiro, penerjemah. Bandung: Institut Teknologi Bandung. Terjemahan dari Phytochemical Method

12. Mokbel, M.S and F. Hashinaga, 2005, Antibacterial and Antioxidant Activities of Banana (Musa, AAA cv. Cavendish) Fruits Peel, American Journal of Biochemistry and Biotechnology 1 (3): 125-131

13. Backer, CA., and RCB Van Den Brink, 1963. Flora of Java. Volume I (III). NV. Noordhoff, Groningen, The Netherlands
14. Van Steenis, C.G.G.J. 1981. Flora untuk Sekolah Indonesia. PT. Pradnya Paramita, Jakarta

15. Pepato MT., RH. Migliorini, AL. Goldberg and IC. Kettelhud. 1996. Role of Different Proteolytic Pathways In Degradation of Muscle Protein From Streptozotocin-Induced Rats. 271:E340-E347

16. Flatt, S.K. Swanston., C. Day, C.J. Bailey and P.R. Flatt. 1990. Traditional Plant Treatments for Diabetes. Studies In Normal and Streptozotocin Diabetic Mice, Diabetologia. 33(8):462-464

17. Rajkumar L.,N. Srinivasan, K. Balasubramanian, P. Govindarajulu. 1991. Increased Degradation of Dermal Collagen In Diabetic Rats. Indian J. Exp. Biol. 29:1081-1083

18. Muraay, R. K., D.K. Granner, P. A. Mayes, and V. M. Rodwell. 2003; Shahib, 1984. Biokimia Harper. Edisi 24. Penerjemah : Hartono, A. EGC Jakarta

19. Robertson, R.P., Y. Tanaka, H. Takahashi, P.O.T. Tran, and J.S. Harmon. 2005. Prevention of Oxidative Stress by Adenoviral Overexpression of Glutathione-Related Enzymes In Pancreatic Islets. Annals of the New York Academy of Sciences, vol.1043, pp. 513-520

20. Savu, O., C. Ionescu Tirgoviste, V. Atanasiu, L. Gaman, R. Papacocea, and I. Stoian. 2012. Increase In Total Antioxidant Capacity of Plasma Despite High Levels of Oxidative Stress In Uncomplicated Type 2 Diabetes Mellitus. The Journal of International Medical, vol. 40, pp. 709-716

21. Palmer, H.J., and K.E. Paulson. 1997. Reactive Oxygen Species and Antioxidants In Signal Tranduction and Gene Expression. Nutritional Review 55 (10):353-361

22. Shirwaikar, A., K. Rajendran, and C.D. Kumar. 2004. Oral Antidiabetic Activity of Annonasquamosa Leaf Alcohol Extract In NIDDM Rats. Pharm.Biol. 42:30-35

23. Lopez, R. Ridaura, W.C. Willet, E.B. Rimm, S. Liu, M.J. Stampfer, J.E. Manson, F.B. Hu. 2004. Magnesium Intake and Risk of Type 2 Diabetes In Men and Women. Diabetic Care 27:134-140

24. Sumadewi, N.L. Utari, 2011. Isolasi Senyawa Tanin Dan Uji Efek Hipoglikemik Ekstrak Kulit Batang Bungur (Lagerstroemia Speciosa Pers.) Terhadap Darah Mencit Yang Diinduksi Aloksan. [Tesis]. Universitas Udayana, Denpasar

25. Dalimartha, S. 2005. Ramuan Tradisional Untuk Pengobatan Diabetes Mellitus. Penerbit Penebar swadaya. Bogor 